\title{
Visible Hand: Do Government Subsidies Promote Green Innovation Performance - Moderating Effect of Ownership Concentration
}

\author{
Haoqiang Wu ${ }^{1}$, Shulin Liu ${ }^{1}$, Sumin Hu ${ }^{1,2 *}$ \\ ${ }^{1}$ School of Economics, Wuhan University of Technology, Wuhan, China \\ ${ }^{2}$ Suzhou University of Science an Technology, Wuhan, China
}

Received: 8 February 2020

Accepted: 6 June 2020

\begin{abstract}
Enterprise green innovation is an important way to promote sustainable development of the environment. This paper focuses on the impact of government subsidies on enterprise green innovation, as well as the moderating role of ownership concentration on the relationship. Using China's data on high-tech enterprises listed in Shanghai and Shenzhen from 2011 to 2016, the hypotheses are tested. The results suggest that: government subsidies effectively improve the enterprises green innovation performance; ownership concentration displays a positively U-shaped effect in relation to green innovation; equity concentration has an inverted U-shaped moderating effect on the relationship between government subsidies and green innovation performance. Moreover, the baseline conclusions applied to SOEs do not apply to non-SOEs. Thus, an integrated framework of public supported resources and internal governance is built to improve the efficiency of government subsidies to develop green new technologies and ultimately promote the sustainability of the environment.
\end{abstract}

Keywords: government subsidies, ownership concentration, enterprise green innovation, property rights

\section{Introduction}

In the new era of high-quality economic development, green innovation has become an important way to realize the green progress of the manufacturing industry [1]. As an important bridge for integrating technology and the economy, enterprises should be the mainstay of decision-making that guide

*e-mail: alvahsm@whut.edu.cn
$R \& D$ investment and the transformation of results in green innovation. However, according to a recent report, from 2014 to 2017, China's green innovation activities are most active in domestic universities and foreign companies. Among the top 20 applicants for green patent applications in China in 2017, there were 17 domestic applicants including 13 universities, 3 enterprises, and 3 foreign enterprises [2]. This shows that China's green and new technology research and development (R\&D) dominated by colleges and universities, face serious problems of insufficient enterprise motivation 
and capabilities. In order to strengthen the innovation capability of enterprises and to alleviate the financing constraints faced by enterprises, various measures have been taken by the government to improve the macro environment and meet the profitability needs of enterprises [3-4], of which government subsidies are an important component [5-6].

Government subsidies are used to achieve a variety of policy goals through financial compensation for enterprises and have an important influence on guiding enterprises in green innovation, additionally, they gradually become an important promoter of China's manufacturing upgrade. Whether or not government subsidies can effectively improve the enterprises remains a controversial issue [7-12]. As such, this paper focuses on analyzing the impact of government subsidies on green innovation, as well as the moderating effect of ownership concentration in this process to give an insight into the reasons for these long-standing disputes. According to corporate governance theory, corporate ownership concentration would explain these dynamic differences [13-14]. Ownership concentration is supposed to depict the structure of the shareholders' meeting, which could possibly affect the operation: resource allocation of enterprises through the variation of two agency costs (the first kind of agency cost is between shareholders and management; and the second is between large shareholders and small shareholders) [15-17]. Although a large portion of the literature on this topic has already identified the relationship between government subsidies or ownership concentration and green innovation $[8,11]$, there are a few studies connecting these two perspectives and the yet-tobe-discussed issues on the green innovation domain, namely, the connection of government subsidies, ownership concentration, and green innovation. Halkos and Skouloudis point out that both institutional efficiency and the quality of governance are necessary divers in developing and diffusing green technology [18]. Thus, the introduction of the moderating role of ownership concentration is conducive to clarifying the micro-mechanism from the perspective of internal governance.

In addition, according to the nature of ownership, enterprises of China can be classified into state-owned enterprises (SOEs) and non-state-owned enterprises (non-SOEs) [19-22]. Due to the special attribute of property rights, remarkable differences between SOEs and non-SOEs in terms of resource acquisition, management privileges, and internal governance structure are expected [23-24]. Thus, this paper will further explore the differences between SOEs and non-SOEs through studying the interaction among ownership concentration, government subsidies, and corporate green innovation. Based on the sample of the manufacturing enterprises in Shanghai and Shenzhen stock markets from 2011-2016, this paper establishes a comprehensive research framework that integrates government subsidies, ownership concentration, and corporate green innovation to explore the specific role of government subsidies on green innovation, as well as the moderating effect of ownership concentration in the relationship between the two. Moreover, this paper also extends the analysis from the property heterogeneity aspect.

To sum up, this paper provides three important contributions to the existant literature. Motivated by the limited empirical attention to internal governance as a moderator of subsidy to promote green innovation, this paper takes on a micro-level perspective and attempts to integrate government subsidy, green innovation, and ownership concentration into a more systematic analysis framework to explore the specific role of government subsidy on green innovation. In particular, this paper attempts to analyze the causal effect of government subsidies on enterprises' green technology innovation from the perspective of the moderating effect of internal governance, which offers a novelty perspective on the long-running dispute of subsidy effect and, thereby, further extends this issue into a new realm. Moreover, this paper also extends the analysis from the property heterogeneity aspect. Therefore, this paper will contribute to previous literature on green innovation research by investigating the causal effect between public subsidies and enterprise green innovative behaviors through an internal moderate mechanism, which will give an insight into how subsidies works in disciplined corporate pollution behaviors.

\section{Literature and Hypothesis}

\section{The Effect of Government Subsidies}

The core function of government subsidies is to solve the problem of investments that are insufficient in $R \& D$ and the excessive $R \& D$ costs caused by externalities, which are expected as the main method to encourage innovation. At present, the effect of government subsidies on enterprise innovation has not been clearly drawn. The positive opinions imply that public subsidies are likely to alleviate the financing needs of enterprises [25-28], reduce the marginal cost and innovation of enterprise thresholds, diversify the risks of R\&D projects, and increase the income expectations for innovation activities [29], thereby increasing the investment in R\&D and expanding the scale of innovation. The negative view of the literature believes that since the distribution and supervision system of government subsidies are not perfect, highvalue subsidies are likely to trigger positive rentseeking behaviors, resulting in high rent-seeking costs that crowd out R\&D investment and reduce the scale of enterprise innovation [30-33]. In comparison, some studies hold that government subsidies have a heterogeneity and moderate scope of effect. Howell believes that government subsidies promote independent innovation of high-tech companies and reduce the total 
factor productivity of low-tech and high-tech industries [32]; Mao and $\mathrm{Xu}$, Yu et al. analyzed the incentive effect of subsidies between districts and further proposed that there is a moderate range of incentives for government subsidies [34]. It means that excessive and too low government subsidies are not conducive to stimulating enterprise innovation.

Green innovation is an innovative activity aimed at improving energy efficiency and achieving the harmonious progression of an enterprising economy and ecological environment [35-37]. Corporate green innovation can meet the government's decisionmaking goals for the harmonious development of the ecological economy, which encourages the government to have a strong incentive to invest public resources into corporate green innovation activities. In the new era of green economy as a development theme, companies can reduce economic costs and environmental externalities through green process innovation and can also use green product research and development to improve corporate financial performance and gain a competitive advantage [38]. Therefore, in the face of huge green innovation market value space and government resource support, enterprises have strong motivation and willingness to commit to green technology innovation. Therefore, hypothesis 1 is proposed as follows:

H1: Government subsidies are positively related to enterprise green innovation performance.

\section{Equity Concentration on Green Innovation}

Equity concentration is the proportion of the shareholder holding shares to total shares, reflecting the company's shareholding structure. According to the findings of previous studies on the role of equity concentration in green innovation, we have classified this paper into five categories. The first category is positive correlation. Equity concentration can provide an effective monitoring mechanism to resolve agency conflict between shareholders and managers caused by equity decentralization, as well as the free rider problem of small and medium shareholders, which can improve the R\&D investment level and productive resource utilization efficiency of enterprises [39]. The second one is the negative correlation. High equity concentration tends to cause the largest shareholder

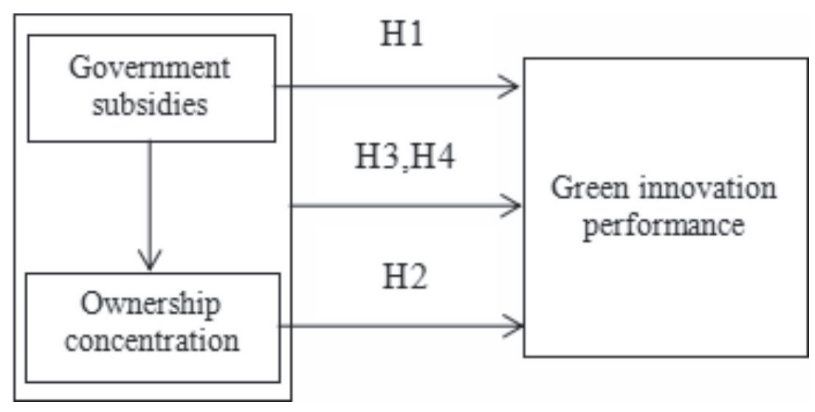

Fig. 1. Role relationship and research hypothesis. to enhance the motivation and ability to pursue nonSOEs or to interfere excessively with management's normal business decisions and behaviors according to personal preferences, thereby affecting corporate development [40-41]. The third category is the irrelevant relationship. The shareholding structure is the result of the shareholders' transactions in order to maximize the benefits and is not closely related to enterprise development [42]. The fourth category is the inverted U-shaped relationship. The balanced equity structure formed by moderate equity concentration can effectively suppress the control right income and the agent's income tendencies. The excessive and low concentration of equity can lead to conflicts and inconsistencies among the largest shareholder and the small and medium shareholders and managers [19]. The last category is the positive U-shaped effect. When the shareholding ratio of the major shareholder is low, the motive and degree of the large shareholder's encroachment on the benefit of the minority shareholders will be enhanced with the increase of the shareholding ratio, resulting in entrenchment effect. When the shareholding ratio reaches a certain threshold, the majority shareholders' incomes from the encroachment of small and mediumsized shareholders' interests is lower than the loss caused by the interest encroachment leading to the decline of corporate performance, prompting the major shareholders and small and medium-sized shareholders to form an alignment effect [43].

According to the studies above, in the era of green economy where enterprises have not yet become the mainstay of green innovation, the stability of the environment in which the enterprise is located is relatively poor, which makes it easier for the equity concentration and green technology innovation to form a positive U-shaped relationship. When the equity structure is excessively dispersed, the members of the shareholders' meeting are likely to form mutual free-riding behaviors. While the managers have greater authority over corporate decision-making and development, they are less affected by shareholder meetings during business processes, which is conducive to timely and effective responses to unstable environments. With the increase of equity concentration, the motivation and ability of the largest shareholder to supervise the manager's business behaviors are also enhanced. However, the income generated by the manager's supervision is lower than the loss caused by the intervention manager's operation, which affects the enterprise's green innovation activities. When the equity concentration exceeds a certain threshold, the maximization of the individual interests of the major shareholders will be highly consistent with the sustainable development of the company, which will enhance the ability of enterprises to cope with environmental uncertainties and to encourage enterprises to continuously optimize the monitoring mechanism to solve various conflicts of interest. Thus, hypothesis 2 is proposed as follows: 
H2: The effect of equity concentration on enterprise green innovation is positively U-shaped.

\section{The Unified Effect}

Government subsidies are regarded as external governance mechanisms, while equity concentration is an internal counterpart. Therefore, equity concentration is expected to affect the efficiency and quality that government subsidies have on corporate green innovation [18]. Due to a positive U-shaped relation between equity concentration and enterprises' green innovation, the equity concentration is likely to have a complex role in moderating the relationship between government subsidies and corporate green innovation.

When the ownership structure is excessively dispersed, there will be a passive effect, which will result in government subsidies not being used efficiently, thus weakening the positive role of government subsidies in corporate green innovation. The mechanism of action is mainly reflected by the excessively dispersed shareholding structure that is not conducive to shareholders' effective supervision and management of managers' business behaviors, subsequently, making it easy for shareholders to form a free rider effect, which leads to the closure and exclusivity of business operations, resulting in the inefficient use of government subsidies. The lack of supervision and the free riding effect caused by an excessively dispersed ownership structure can easily lead to fraud and rent-seeking behavior, leading to policy failure and the waste of public resources [44-45]. When the equity concentration exceeds a certain threshold, the maximization of personal benefits of major shareholders are consistent with the long-term development of enterprises. In order to seize the opportunity of green economy development, major shareholders must improve the internal control mechanism and optimize the resource allocation mechanism to efficient use of the government's support resources to enhance the ability of green innovation. Thus, hypothesis 3 is proposed as follows:

H3: The equity concentration has a positive U-shaped moderating effect on the role of government subsidies in corporate green innovation.

\section{Property Heterogeneity}

The nature of property rights determines a series of internal governance issues such as corporate equity structure, decision-making, and implementation and incentive mechanisms [46]. Therefore, due to the different nature of property rights, there are significant differences in the technological innovation behaviors, goals, and business environments of each enterprise [19-20]. The particularity of SOEs property rights is reflected in: (1) SOEs have a large amount of productive resources from the government since they were founded and can obtain monopoly power and scarce quality resources at low cost through a large number of rentseeking opportunities [24]; (2) SOEs have various developmental goals; while seeking to preserve and increase the value of state-owned assets, they also need to fulfill the social high-quality developmental goals of the country and have social functions such as promoting the green development of the economy and technology; and (3) entrepreneurs in state-owned enterprises are decision-makers appointed by government agencies; most of them have never had professional training, lack risk awareness and market competition thinking, and innovative management capabilities, however, in the process of operations, non-SOEs need to be responsible for their own profits and losses, which is the fundamental purpose to improve the core technical capabilities and realize the value preservation of assets. This encourages non-SOEs to make more efficient use of external support resources to improve their ability to reach green innovation. Thus, the hypothesis 4 is as follows:

H4: The relationship among equity concentration, government subsidies, and corporate green technology innovation of SOEs and non-SOEs is significantly different

\section{Experimental}

Data and Samples

According to the availability of the relevant data set, this paper uses the high-tech enterprises listed in Shanghai and Shenzhen stock markets over the period of 2011 to 2016 as the research sample. After eliminating the non-continuous operations: variables with severe missing data, and the ST-type samples, 589 listed companies and 2,306 observations of unbalanced panel data were obtained. All the data comes from the Wind Information Financial Terminal, the China Stock Market \& Accounting Research Database (CSMAR), the State Intellectual Property Office's official website, and Baiten's official website. The green patent data are from the State Intellectual Property Office website and Baiten's official website. Other data are mainly from the Wind Information Financial Terminal and the CSMAR database.

According to the contribution of $\mathrm{Li}$ and colleagues [47] and Berrone and colleagues [48] and data available in China, enterprise green technology innovation performance (Gpatent) is measured by green patent applications. The green patent applications data were collected by $\mathrm{Li}$ and colleagues [47], in which 14 Chinese keywords were used to screen the patent applications of sample companies to obtain the specific green technology innovation data. Keywords that demonstrated the conception and meaning of green technology innovation included environmental protection, energy saving, pollution control, water 
conservation, electricity saving, recycling, sustainable, clean, economical, emission reduction, green, low carbon, environmental protection, and ecology.

\section{Research Model}

Drawing on the research methods of Wen and Ye [49], Du et al. [50], Edwards and Lambert [51], this paper builds empirical models one through four, which use the enterprise green technology innovation patents as the dependent variable, and government subsidies, equity concentration, and interaction items as explanatory variables to examine the effect of subsidies and equity concentration on green innovation. Some control variables have been added, that include company size, equity balance, and equity incentives of the core technical personnel.

$$
\begin{aligned}
& \text { Gpatent }_{i, t}=\alpha_{0}+\alpha_{1} \text { shr } 2-10_{i, t}+\alpha_{2} \text { size }_{i, t}+\alpha_{3} \text { tepo }_{i, t}+\varepsilon_{i, t} \\
& \text { Gpatent }_{i, t}=\beta_{0}+\beta_{1} \ln _{\text {gosub }_{i, t}}+\beta_{i} \text { Controls }_{i, t}+\varepsilon_{i, t} \\
& \text { Gpatent }_{i, t}=\gamma_{0}+\gamma_{1} \operatorname{lngosub}_{i, t}+\gamma_{2} \operatorname{shr}_{i, t}+\gamma_{3} \operatorname{shrl}_{i, t}^{2} \\
& +\gamma_{i} \text { Controls }_{i, t}+\varepsilon_{i, t}
\end{aligned}
$$

$$
\begin{aligned}
& \text { Gpatent }_{i, t}=\varphi_{0}+\varphi_{1} \ln _{\text {gosub }_{i, t}}+\varphi_{2} \text { shr }_{i, t}+\varphi_{3} \text { shrl }_{i, t}^{2} \\
& +\varphi_{4} \ln _{\text {gosub } \times \text { shr1 }^{2}}{ }_{i, t}+\varphi_{5} \text { Controls }_{i, t}+\varepsilon_{i, t}
\end{aligned}
$$

Where (1 4) Gpatent is the dependent variable, which is expressed as the enterprise green innovation performance and measured by the total amount of green patents applied for by the enterprise. In the explanatory variables, lngosub is government subsidies, which is expressed by the natural logarithm of the current government subsidy (in millions of RMB); shrl is equity concentration is the proportion of shares held by the largest shareholder; $s h r l^{2}$ is the square of equity concentration; lngosub $\times$ shrl ${ }^{2}$ is the intersection of government subsidy and equity concentration squared. Controls is the control variables expressed by equity balance (shr2-10), enterprise size (size), and equity incentives for core technicians (tepo). Among them, the equity balance is expressed as the sum of the shareholding ratio of the second to the tenth largest shareholders; the enterprise size is the total assets (in units of 100 million yuan); and equity incentives for core technicians are expressed as a percentage of equity acquired by core technicians.

\section{Descriptive Analysis}

Table 1 shows the descriptive analysis of the main variables. The quantile 1, median, quantile 3, and the mean value of green patent applications are 47, 21,8 , and 66.314, respectively. This means that the willingness and output of green innovation among different manufacturing companies are significantly different. The quantile1, median, quantile 3 and mean value of government subsidies are 1.811, 2.635, 3.647, and 2.716. This means that there is a big difference in government subsidies received between sample companies. In summary, the research sample companies have better differentiation.

\section{Results and Discussion}

\section{Basic Empirical Results Analysis}

STATA 15.0 is applied in this paper to process data and baseline models to examine the hypotheses for the relationship among ownership concentration, government subsidies and corporate green innovation.

In Table 2, columns one through three show the successive regression results among control variables (shr2-10, size, and tepo), government subsidies (lngosub), ownership concentration (shr1), equity concentration squared (shrl_squ) and green technology innovation (Gpatent). Column four shows the regression results after adding the intersection of government subsidy and equity concentration squared on the basis of the column three.

In Table 2, the regression coefficient of government subsidies (lngosub) is 19.97, which is statistically significant. Thus, the role of government subsidies in corporate green innovation is significantly positive (Gpatent). As government subsidies increase, companies are able to acquire more external resources, which makes green innovation performance better. Therefore, Hypothesis 1 is supported.

Table 1. Descriptive statistical analysis of the main variables.

\begin{tabular}{|c|c|c|c|c|c|c|}
\hline Variable & Obs & Mean & Std. Dev. & Quantile1 & median & Quantile3 \\
\hline Gpatent & 2,306 & 66.314 & 178.404 & 8 & 21 & 47 \\
\hline gosub & 2,306 & 2.716 & 1.485 & 1.811 & 2.635 & 3.647 \\
\hline shr1 & 2,306 & 32.932 & 13.514 & 22.360 & 30.630 & 41.620 \\
\hline shr2-10 & 2,306 & 23.235 & 12.405 & 13.66 & 21.570 & 31.550 \\
\hline tepo & 2,306 & 0.092 & 0.265 & 0 & 0 & 0 \\
\hline size & 2,306 & 21.925 & 1.153 & 21.102 & 21.815 & 22.566 \\
\hline
\end{tabular}




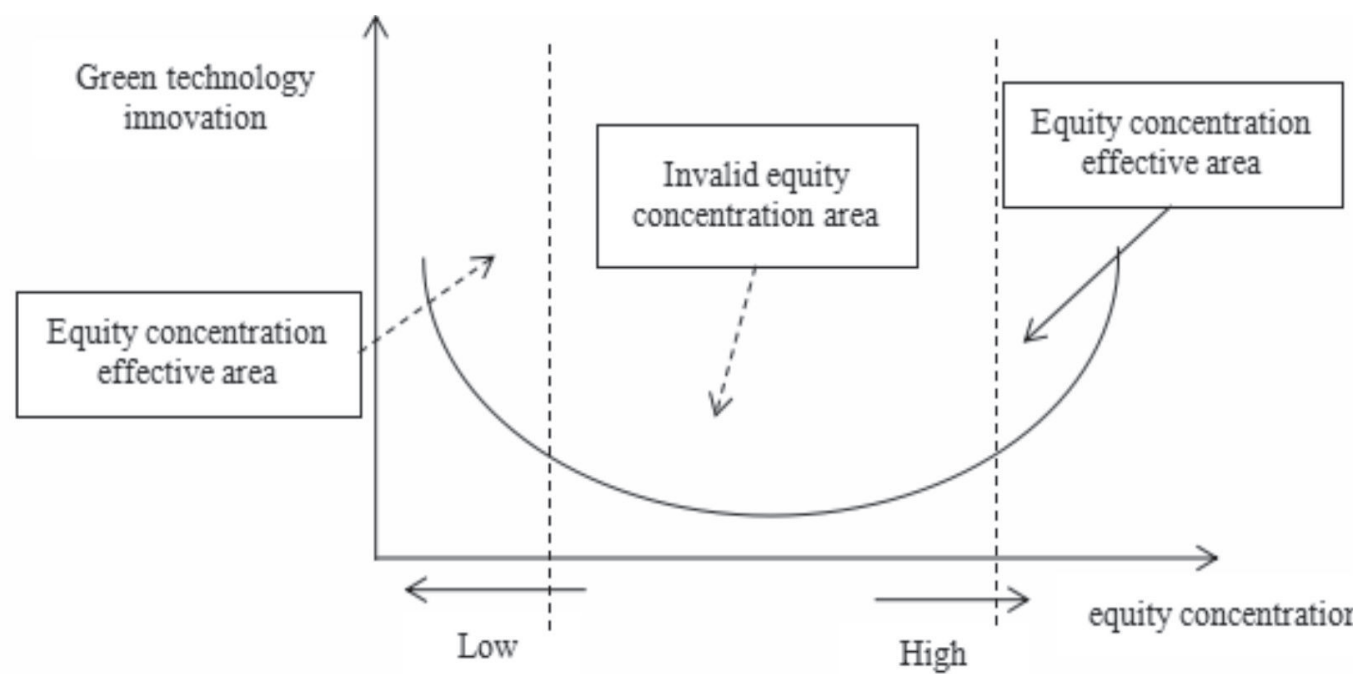

Fig. 2. Positive U-shaped effect of equity concentration on green innovation.

Regression results also show that the effect of equity concentration on corporate green innovation is positive and U-shaped. From columns three and four, the regression coefficient of ownership concentration squared is significantly positive, which indicates that the effect of ownership concentration on corporate green innovation is positive U-shaped. As the concentration of equity increases, the ability of enterprises to cope with the unstable environment is enhanced, while selfinterest motives and capabilities of major shareholders

Table 2 The basic regression results.

\begin{tabular}{|c|c|c|c|c|}
\hline & (1) & (2) & (3) & (4) \\
\hline & Gpatent & Gpatent & Gpatent & Gpatent \\
\hline \multirow{2}{*}{ shr2-10 } & $2.005^{* * *}$ & $1.990^{* * *}$ & $1.831^{* * *}$ & $2.148^{* * *}$ \\
\hline & $(4.22)$ & $(4.20)$ & $(3.57)$ & $(4.21)$ \\
\hline \multirow{2}{*}{ size } & $88.64^{* * *}$ & $70.42^{* * *}$ & $69.83^{* * *}$ & $75.27^{* * *}$ \\
\hline & $(17.32)$ & $(9.82)$ & $(9.74)$ & $(10.53)$ \\
\hline \multirow{2}{*}{ tepo } & 5.540 & 2.177 & -0.529 & 0.314 \\
\hline & $(0.25)$ & $(0.10)$ & $(-0.02)$ & $(0.01)$ \\
\hline \multirow{2}{*}{ lngosub } & & $19.97^{* * *}$ & $19.41^{* * *}$ & $48.44^{* * *}$ \\
\hline & & $(3.62)$ & $(3.52)$ & $(6.96)$ \\
\hline \multirow{2}{*}{ shrl } & & & $-5.313^{* *}$ & $-6.625^{* * *}$ \\
\hline & & & $(-2.73)$ & $(-3.43)$ \\
\hline \multirow{2}{*}{ shr1_squ } & & & $0.0650^{*}$ & $0.148^{* * *}$ \\
\hline & & & $(2.54)$ & $(5.26)$ \\
\hline \multirow{2}{*}{ lngosub*shrl_squ } & & & & $-0.0218^{* * *}$ \\
\hline & & & & $(-6.74)$ \\
\hline \multirow{2}{*}{ _cons } & $-1917.3^{* * *}$ & $-1571.5^{* * *}$ & $-1460.5^{* * *}$ & $-1651.3^{* * *}$ \\
\hline & $(-16.74)$ & $(-10.54)$ & $(-9.48)$ & $(-10.64)$ \\
\hline$N$ & 2303 & 2303 & 2303 & 2303 \\
\hline$R^{2}$ & 0.116 & 0.121 & 0.124 & 0.141 \\
\hline $\operatorname{adj} . R^{2}$ & 0.115 & 0.120 & 0.122 & 0.139 \\
\hline
\end{tabular}

$t$ statistics in parentheses; ${ }^{*} p<0.05,{ }^{* *} p<0.01,{ }^{* * *} p<0.001$ 
are enhanced. When the concentration of equity has not exceeded a certain threshold, the losses caused by the majority shareholders' self-interest will be greater than the gains from the improvement of the operational efficiency of the enterprise. When the ownership structure is highly concentrated, the maximization of the individual interests of the major shareholders will be highly consistent with the sustainable development of the company, which will enhance the ability of enterprises to cope with environmental uncertainties, and encourage enterprises to continuously optimize supervision mechanisms to solve various conflicts of interest and ultimately achieve the improvement of green innovation performance (Fig. 2). Thus, Hypothesis 2 is supported as expected.

However, the coefficient of the squared intersection is significantly negative, which indicates that the equity concentration has an inverted U-shaped effect on the role of government subsidies in corporate green innovation. When the equity concentration is low, the equity concentration positively adjusts the impact that government subsidies have on corporate green innovation. When the equity concentration is high, the equity concentration negatively adjusts the effect that government subsidies have on corporate green innovation. Therefore, Hypothesis 3 is not supported.

The reason why Hypothesis 3 is not supported may be caused by the heterogeneity between government subsidized resources and internal productive resources. The heterogeneity is reflected in the information asymmetry, the distribution and supervision mechanism for government R\&D subsidies which is weaker than that for internal productive resources and is conducive to enhancing the motive for encroachment of corporate decision makers. When the ownership structure is excessively dispersed and as the concentration of equity increases, shareholders' supervision of managers will also become stronger, which enhances the promotion of government subsidies to green innovation. When the concentration of equity exceeds a certain threshold, the imperfect distribution and supervision mechanisms of government subsidies tend to enhance the motives of the largest shareholder's encroachment, which reduces the efficiency of government subsidies.

\section{Heterogeneity Analysis of Property Rights}

In Table 3, columns one and two show the successive regression results among the control variables: government subsidies, equity concentration, equity concentration squared, and green innovation from property rights. Columns three and four show the regression results of the test of relationships among the explanatory variables and control variables and green innovation after adding the intersection of government subsidy and equity concentration squared on the basis of the column two from the perspective of property rights.

Columns one and two show that the regression coefficients of government subsidies of non-SOEs and SOEs are 11.31 and 27.23, respectively, in which the former is statistically significant and the latter is not statistically significant. It shows that the role of government subsidies in corporate green innovation is significantly positive for non-SOEs. The regression coefficient of equity concentration squared of nonSOEs is not significant, while the result of state-owned enterprises is significantly positive, which indicates that the positive U-shaped relationship of equity concentration to the green innovation applies to SOEs, not to non-SOEs.

From the columns three and four, the regression coefficients of government subsidies of non-SOEs and SOEs are 10.86 and 107.1, respectively; both are statistically significant. Thus, the positive effects of government subsidies on corporate green innovation

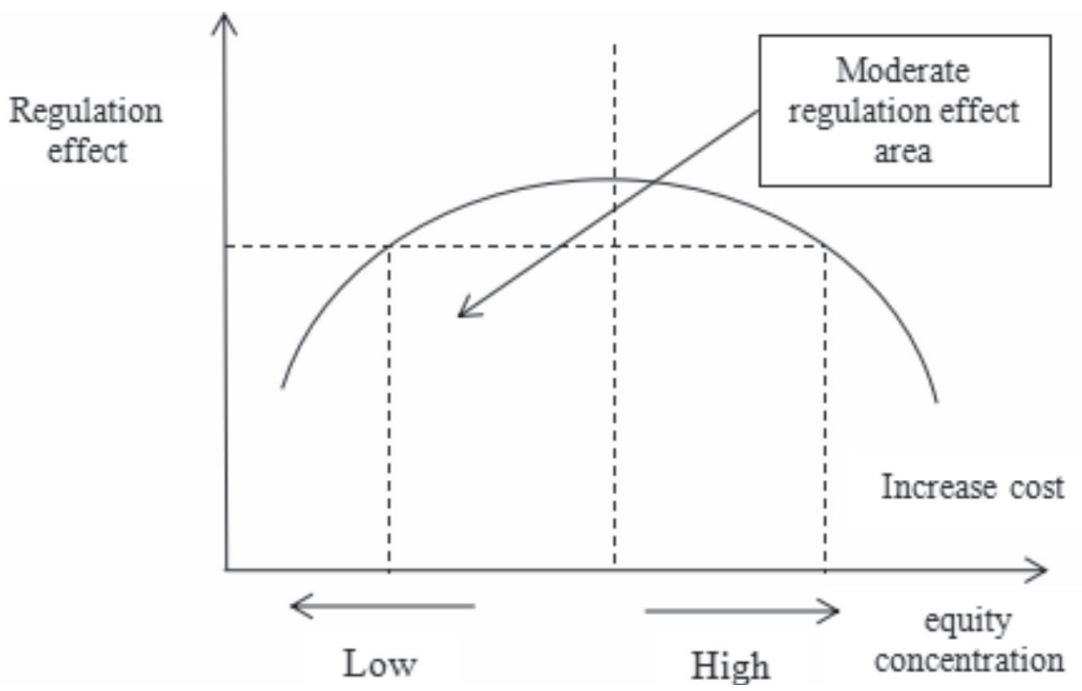

Fig. 3. The inverse U-shaped moderating effect of equity concentration on the role of government subsidies in green innovation. 
Table 3. Regression results from the perspective of property heterogeneity.

\begin{tabular}{|c|c|c|c|c|}
\hline & (1) & (2) & (3) & (4) \\
\hline & (Non-SOEs) & (SOEs) & (Non-SOEs) & (SOEs) \\
\hline \multirow{2}{*}{ lngosub } & $11.31^{* * *}$ & 27.23 & $10.86^{*}$ & $107.1^{* * *}$ \\
\hline & $(3.32)$ & (1.77) & $(2.32)$ & $(5.75)$ \\
\hline \multirow{2}{*}{$\operatorname{shrl}$} & 0.184 & $-31.03^{* * *}$ & 0.176 & $-41.19^{* * *}$ \\
\hline & $(0.16)$ & $(-4.96)$ & $(0.15)$ & $(-6.63)$ \\
\hline \multirow{2}{*}{ shr1_squ } & 0.0130 & $0.311^{* * *}$ & 0.0122 & $0.642^{* * *}$ \\
\hline & $(0.82)$ & $(4.02)$ & $(0.72)$ & (7.29) \\
\hline \multirow{2}{*}{ shr2-10 } & $1.681^{* * *}$ & 0.697 & $1.680^{* * * *}$ & 1.446 \\
\hline & $(5.41)$ & $(0.39)$ & $(5.40)$ & $(0.84)$ \\
\hline \multirow{2}{*}{ size } & $49.02^{* * *}$ & $103.3^{* * *}$ & $49.02^{* * *}$ & $121.0^{* * *}$ \\
\hline & $(10.85)$ & $(4.92)$ & $(10.85)$ & $(5.92)$ \\
\hline \multirow{2}{*}{ tepo } & 0.893 & 181.2 & 0.806 & 163.1 \\
\hline & $(0.08)$ & (1.36) & $(0.07)$ & $(1.26)$ \\
\hline \multirow{2}{*}{ lngosub*shr1_squ } & & & 0.000364 & $-0.0545^{* * *}$ \\
\hline & & & $(0.14)$ & $(-7.10)$ \\
\hline \multirow{2}{*}{ _cons } & $-1102.1^{* * *}$ & $-1645.6^{* * *}$ & $-1100.9^{* * *}$ & $-2162.9^{* * *}$ \\
\hline & $(-11.36)$ & $(-3.58)$ & $(-11.29)$ & $(-4.80)$ \\
\hline$N$ & 1596 & 701 & 1596 & 701 \\
\hline$R^{2}$ & 0.154 & 0.172 & 0.154 & 0.228 \\
\hline $\operatorname{adj} . R^{2}$ & 0.151 & 0.165 & 0.151 & 0.221 \\
\hline
\end{tabular}

$t$ statistics in parentheses; ${ }^{*} p<0.05,{ }^{* *} p<0.01,{ }^{* * *} p<0.001$

are unstable in SOEs. The regression results of the equity concentration squared of non-SOEs and SOEs are basically consistent with the results in columns one and two. In terms of the results of the intersection of government subsidies and equity concentration squared, the inverted U-shaped adjustment effect of equity concentration on the role of government subsidies in green innovation is applicable to SOEs and not to non-SOEs. Therefore, Hypothesis 4 is supported.

In terms of the control variables, the regression coefficient of the equity balance of non-SOEs is significantly positive and the state-owned enterprises is not significantly positive. It shows that the equity balance of non-SOEs is conducive to the formation of appropriate checks and balances on the authority of major shareholders for improving the green innovation performance.

To sum up, government subsidies is able to promote the improvement of green innovation performance as expected, which applies to non-SOEs, and unstable in state-owned enterprises; The effect of equity concentration on corporate green innovation is positive U-shaped, which applies to SOEs and does not apply to non-SOEs; the equity concentration has an inverse U-shaped moderating effect on the role of government subsidies on green innovation, which applies to SOEs and does not apply to non-SOEs

\section{Robustness Test}

To sum up, government subsidies are able to promote the improvement of green innovation performance as expected, which applies to non-SOEs, and unstable in state-owned enterprises. The effect of equity concentration on corporate green innovation is positive and U-shaped, which applies to SOEs and does not apply to non-SOEs. The equity concentration has an inverse U-shaped moderating effect on the role of government subsidies on green innovation, which applies to SOEs and does not apply to non-SOEs.

\section{Robustness Test}

In order to ensure more robust conclusions, this paper further tested the relationship among equity concentration, government subsidies, and green innovation from two perspectives.

First, this paper will add control variables that may influence green innovation which was calculated as the proportion of independent directors (the 
proportion of independent directors in the board, indir) and the salary incentives of directors, supervisors, and senior managers (the total annual salary, in units of one million yuan, chsas). Thus, the empirical model is five, with results in columns one and two.

$$
\begin{aligned}
\text { Gpatent }_{i, t} & =\eta_{0}+\eta_{1} \text { Var }_{i, t}+\eta_{2} \text { shr } 2-10_{i, t}+\eta_{3} \text { size }_{i, t}+\eta_{4} \text { tepo }_{i . t} \\
& +\eta_{5} \text { indir }_{i, t}+\eta_{6} \text { chsas }_{i, t}+\varepsilon_{i, t}
\end{aligned}
$$

Second, this paper will select the marketization degree in the region where the enterprise is located as a substitute for government subsidies. The reason for choosing the degree of marketization (Market) as a substitution variable is that the degree of marketization in a region determines the external living environment and external governance quality of the enterprise and has an important impact on the setting of government subsidy mechanisms. Thus, the empirical model is (6), with results in columns three and four

$$
\begin{aligned}
\text { Gpatent }_{i, t}= & \mu_{0}+\mu_{1} \text { Market }_{i, t}+\mu_{2} \text { shr }_{i, t}+\mu_{3} \operatorname{shr}_{i, t}^{2} \\
& +\mu_{4} \text { mash }_{i, t}+\mu_{5} \text { Controls }_{i, t}+\varepsilon_{i, t}
\end{aligned}
$$

The degree of marketization of the company's region is measured by the Wang et al. China

\begin{tabular}{|c|c|c|c|c|}
\hline & (1) & (2) & (3) & (4) \\
\hline & (Non-SOEs) & (SOEs) & (Non-SOEs) & (SOEs) \\
\hline \multirow{2}{*}{ lngosub } & 8.472 & $96.03^{* * *}$ & & \\
\hline & $(1.84)$ & $(5.27)$ & & \\
\hline \multirow{2}{*}{ shrl } & 0.107 & $-38.92^{* * *}$ & -0.305 & $-24.46^{* * *}$ \\
\hline & $(0.09)$ & $(-6.42)$ & $(-0.21)$ & $(-3.60)$ \\
\hline \multirow{2}{*}{ shr1_squ } & 0.0110 & $0.613^{* * *}$ & 0.0137 & $0.308^{* * *}$ \\
\hline & $(0.66)$ & (7.14) & $(0.86)$ & (3.99) \\
\hline \multirow{2}{*}{ interac } & 0.000209 & $-0.0564^{* * *}$ & & \\
\hline & $(0.08)$ & $(-7.54)$ & & \\
\hline \multirow{2}{*}{ shr210 } & $1.440^{* * *}$ & -0.493 & $1.645^{* * *}$ & 1.454 \\
\hline & (4.69) & $(-0.29)$ & $(5.28)$ & $(0.81)$ \\
\hline \multirow{2}{*}{ indir } & $331.4^{* * *}$ & -363.3 & & \\
\hline & $(5.14)$ & $(-1.30)$ & & \\
\hline \multirow{2}{*}{ chsas } & $4.342^{* * *}$ & $26.79^{* * *}$ & & \\
\hline & $(6.01)$ & $(6.19)$ & & \\
\hline \multirow{2}{*}{ size } & $39.26^{* * *}$ & $85.73^{* * *}$ & $58.64^{* * *}$ & $129.6^{* * *}$ \\
\hline & (7.99) & $(4.10)$ & $(16.45)$ & $(9.15)$ \\
\hline \multirow{2}{*}{ tepo } & 0.975 & 55.41 & 1.657 & 189.0 \\
\hline & $(0.09)$ & $(0.44)$ & $(0.14)$ & $(1.43)$ \\
\hline \multirow{2}{*}{ Market } & & & 17.60 & $337.6^{* *}$ \\
\hline & & & $(0.54)$ & $(2.61)$ \\
\hline \multirow{2}{*}{ Mash } & & & 0.336 & $-7.488^{*}$ \\
\hline & & & $(0.30)$ & $(-2.18)$ \\
\hline \multirow{2}{*}{ _cons } & $-1021.0^{* * *}$ & $-1346.0^{* *}$ & $-1292.8^{* * *}$ & $-2446.5^{* * *}$ \\
\hline & $(-9.27)$ & $(-2.94)$ & $(-14.59)$ & $(-6.76)$ \\
\hline$N$ & 1596 & 701 & 1596 & 701 \\
\hline$R^{2}$ & 0.188 & 0.271 & 0.151 & 0.178 \\
\hline $\operatorname{adj} . R^{2}$ & 0.184 & 0.261 & 0.147 & 0.169 \\
\hline
\end{tabular}
Marketization Index [52]. In this paper, the provinces with a marketiszation index higher than the mean

Table 4. Results of robustness test.

$t$ statistics in parentheses; ${ }^{*} p<0.05,{ }^{* *} p<0.01,{ }^{* * *} p<0.001$ 
value are marked as 1 , and the provinces with a lower than mean value are marked as 0 , thereby obtaining a virtual variable of the degree of marketization for each province. The intersection of government subsidy and equity concentration squared is expressed as mash.

Table 4 depicts that the robustness test results in both scenarios are basically consistent with the test results in Table 3, which are mainly reflected as government subsidies of PE and SOEs having positive effects on green technology innovation. The positive U-type effect of equity concentration on green technology innovation still applies to SOEs and not to non-SOEs. In columns one and two, the inverse U-shaped adjustment effect of equity concentration on the role of government subsidies in green innovation still applies to SOEs and not to non-SOEs. In columns three and four, the degree of marketization has a positive effect on the innovation of non-SOEs and SOEs. In the column three and four, the inverse U-shaped adjustment effect of equity concentration on the role of marketization degree in green innovation still applies to SOEs and not to nonSOEs. In comparison to Table 3 , the small changes in the other test results in Table 4 do not affect the main conclusions obtained in this paper.

\section{Conclusions}

As the green economy becomes the theme of highquality economic development, green innovation has become an important way to realize green progress in the manufacturing industry. Using listed hightech companies in Shanghai and Shenzhen stock markets, this study sought to investigate the impact of the government subsidies on green innovation by considering the moderating effect of ownership concentration. The following conclusions are drawn:

First, government subsidies effectively improve enterprises green innovation performance. This result is consistent with the findings of Peng and Liu [8, 53] and in conflict with the results of $\mathrm{Yu}$ et al. [14] who found that government subsidies are negatively associated with green innovation. Therefore, the results further clarify the effect of government subsidies on enterprise green innovation.

Second, this study also found that ownership concentration has a positively U-shaped effect on green innovation. This conclusion is consistent with the findings of Wang and Wang [54] who showed that enterprise resources can significantly strengthen green technology innovation only when the shares held by major shareholders are within a certain threshold. Thus, the results further support the finding that the impact of equity concentration on government subsidies is nonlinear.

Third, equity concentration has an inverted U-shaped moderating effect on the relationship between government subsidies and green innovation performance. Combined with a positive U-shaped effect on equity concentration relationship to green innovation. This conclusion indicates that there is heterogeneity between government subsidized resources and internal productive resources of enterprises in the use of supervision and encroachment motivation.

For property heterogeneity, the baseline conclusions apply to SOEs and not to non-SOEs. This conclusion is in line with Jin and Xu's work that there are obvious differences between state-owned enterprises and non-state-owned enterprises in the field of green development [55]. The comparative analysis of stateowned enterprises and non-state-owned enterprises is likely to clarify the applicability boundary of the basic conclusion from the perspective of the heterogeneity of property.

\section{Public Policy Implications}

Some policy implications are provided. First, since government subsidies positively affect corporate green technology innovation, policy-makers should strengthen their support of subsidies for enterprise green innovation. Effective supervision and evaluation systems for these subsidized enterprises are needed to improve the efficiency and quality of government subsidies in promoting environmentally sustainable development by establishing a dynamic supervision mechanism based on application and use procedures. Second, the inverted U-shaped moderating effect of ownership concentration on the relationship between government subsidies and green innovation shows that ownership concentration should be kept at a proper threshold. That is, ownership concentration should not be too high when enterprises improve the utilization efficiency of government subsidies to support green innovation. Third, the results of the heterogeneity of property rights indicates that there are significant enterprise differences in the relationship between government subsidies, ownership concentration, and green innovation. Enterprises need to flexibly adjust and optimize the management of government subsidies and the concentration of equity against actual conditions in the process of green innovation.

Although this paper has attempted to robustly test these hypotheses, there remain some limitations and suggestions for future research. First, although this paper tried to examine the micro-action mechanism of government subsidies on green innovation from internal governance perspectives, we only discussed equity concentration, there are many other internal governance variables which may also affect the relationship that were omitted, such as board structure, equity incentive, and so on. Second, heterogeneous problems are only discussed from the property rights perspective due to data availability. Other heterogeneous issues, such as the heterogeneity of enterprise scales in industries and regions need to be considered in further studies. 


\section{Acknowledgments}

We are grateful to acknowledge support from prof. Qian Yu, prof. Liu for their comments on earlier drafts of this paper, as well as seminar participants at Wuhan University of Technology during the initial writing of this paper. We owe special thanks to Miss Keqin Lee and Miss Jin Chen for their assisting in data collection.

\section{Conflict of Interest}

The authors declare no conflict of interest.

\section{References}

1. GHISETTI C., RENNINGS K. Environmental innovations and profitability: how does it pay to be green? An empirical analysis on the German innovation survey. Journal of Cleaner Production 75 (14), 106, 2014.

2. CHINA NATIONAL INTELLECTUAL PROPERTY ADMINISTRATION. Patent statistics briefing: China green patent statistics report (2014-2017) 14, 2018.

3. UYARRA E., FLANAGAN K. Understanding the innovation impacts of public procurement. European Planning Studies 18, 123, 2010.

4. MAGRO E., WILSON J.R. Complex innovation policy systems: towards an evaluation mix. Research Policy 42, 1647, 2013.

5. KIVIMAA P., KERN F. Creative destruction or mere niche support? Innovation policy mixes for sustainability transitions. Research Policy 45, 205, 2016.

6. HUERGO E., MORENO L. Subsidies or loans? Evaluating the impact of R\&D support programmes. Research Policy 46, 1198, 2017.

7. WANG X., WANG F. No resource or no motivation? Government subsidies,green innovation and incentive strategy selection. Science Research Management 40 (7), 131, 2019.

8. PENG H.T., LIU Y. How government subsidies promote the growth of entrepreneurial companies in clean energy industry: an empirical study in China. Journal of Cleaner Production 188, 508, 2018.

9. HU S.M., LIU S.L. Do the coupling effects of environmental regulation and R\&D subsidies work in the development of green innovation? Empirical evidence from China. Clean Technologies and Environmental Policy 21, 1739, 2019

10. HU S.M., LIU S.L., LI D., LIN Y.X. How does regional innovation capacity affect the green growth performance? Empirical evidence from China. Sustainability 11, 5084, 2019.

11. YU F.F., GUO Y., Le-Nguyen K., BARNES S.J., ZHANG W.T. The impact of government subsidies and enterprises' R\&D investment: a panel data study from renewable energy in China. Energy Policy 89, 106, 2016.

12. KANG K.N., PARK H. Influence of government R\&D support and inter-firm collaborations on innovation in Korean biotechnology SMEs. Technovation 32 (1), 68, 2012.

13. SU D.W., HE X.X. Ownership structure,corporate governance and productive efficiency in China. Journal of Productivity Analysis 38 (3), 303, 2012.
14. SAUERWALD S., PENG M.W. Informal institutions, shareholder coalitions, and principal-principal conflicts. Asia Pacific Journal of Management 30 (3), 853, 2013.

15. CHEN V.Z., LI J., SHAPIRO D.M., ZHANG X. Ownership structure and innovation: an emerging market perspective. Asia Pacific Journal of Management 31 (1), 1, 2014.

16. BOGLIACINO F., PRATO D.G., NEPELSKI D. Ownership structure and R\&D orientation in ICT groups. Eurasian Business Review 3 (2), 164, 2013.

17. SAPRA H., SUBRAMANIAN A., SUBRAMANIAN K.V. Corporate governance and innovation: theory and evidence. Journal of Financial and Quantitative Analysis 49 (4), 957, 2014.

18. HALKOS G., SKOULOUDIS A. Environmental technology development and diffusion: panel data evidence from 56 countries. Environmental Economics and Policy Studies. Online first, 2020.

19. YANG J.J., WANG T., LIU L.B. Ownership concentration and corporation indigenous innovation behavior: from the perspective of behavior motivation. Journal of Management Science 2, 1, 2015.

20. HE Y.L., ZHANG Y.W., MO J.M. The influence of ownership concentration on the corporate performance under difference regional governance environment. Journal of Financial Research 12, 148, 2014.

21. LIN C., LIN P., SONG F. Property rights protection and corporate R\&D: evidence from China. Journal of Development Economics 93 (1) , 49, 2010.

22. CHOI S.B., LEE S.H., WILLIAMS C. Ownership and firm innovation in a transition economy: evidence from China. Research Policy 40 (3), 441, 2011.

23. WU Y.B. Which type of ownership type in China is the most innovative? Journal of World Economy 6, 3, 2012.

24. ZHANG Y.J., TANG X.X. Ownership structure, executive incentive and firm innovation - Based on the data of a share listed companies with different property rights. Journal of Shanxi University of Finance and Economics 40 (9), 76, 2018.

25. BERNINI C., PELLEGRINI G. How are growth and productivity in private firms affected by public subsidy? evidence from a regional policy. Regional Science and Urban Economics 41 (3) ,253, 2011.

26. BROWN J.R., MARTINSSON G., PETERSON B.C. Do Financing constraints matter for R\&D? new tests and evidence. ASSA annual meeting paper2011.

27. CAPPELEN A., RAKNERUD A., RYBALKA M. The effects of R\&D tax credits on patenting and innovations. Research Policy 41 (2), 334, 2012.

28. SHANG H.T., HUANG X.S. Research on the interaction effects among government subsidy, R\&D investment and innovation performance. Studies in Science of Science 36 (3), 446, 2018.

29. GUO D., GUO Y., JIANG K. Government-subsidized R\&D and firm innovation: evidence from China. Research Policy 45 (6), 1129, 2016.

30. CATOZZELLA A., VIVARELLI M. The possible adverse impact of innovation subsidies: some evidence from Italy. International Entrepreneurship \& Management Journal 12 (2), 1, 2014.

31. BOEING P. The allocation and effectiveness of China's R\&D subsidies-evidence from listed firms. Research Policy 45 (9), 1774, 2016.

32. HOWELL A. Picking 'winners' in China: do subsidies matter for indigenous innovation and firm productivity? China Economic Review 44, 154, 2017. 
33. WANG Y.B., LI J.Z., FURMAN J.L. Firm performance and state innovation funding: evidence from China's innofund program. Research Policy 46, 1142, 2017.

34. MAO Q.L., XU J.Y. The effect of government subsidy on firms' new product innovation - an analysis based on the moderate interval of subsidy intensity. China Industrial Economics 6, 94, 2015.

35. JAFFE A.B., PALMER K. Environmental regulation and innovation: a panel data study. Review of Economics \& Statistics 79 (4), 610, 1997.

36. HALKOS G., SKOULOUDIS A. Corporate social responsibility and innovative capacity: Intersection in a macro-level perspective. Journal of cleaner production 182, 291, 2018.

37. KEMP R. Eco-innovation: definition, measurement and open research issues. Economia Politica 27 (3), 397, 2010.

38. DRIESSEN P.H., HILLEBRAND B., KOK R.A.W., VERHALLEN T.M.M. Green new product development: the pivotal role of product greenness. IEEE Transactions on Engineering Management 60 (2), 315, 2013.

39. MA S.H., NAUGHTON T., GARY T. Ownership and ownership concentration: which is important in determining the performance of China's listed firm? Accounting and Finance 50 (4), 871, 2010.

40. WU J., XU D., PHAN P.H. The effects of ownership concentration and corporate debt on corporate divestitures in Chinese listed firms. Asia Pacific Journal of Management 28 (1), 95, 2011.

41. CHEN V.Z., LI J. SHAPIRO D.M. Are OECD-prescribed "good corporate governance practices" really good in an emerging economy? Asia Pacific Journal of Management 28 (1) , 115, 2011.

42. HOLDERNESS C.G., SHEEHAN D.P. The role of majority Shareholders in publicly held corporations: an exploratory analysis. Journal of Financial Economics 20 (2), 317, 1988.

43. LIU C., UCHIDA K., YANG Y. Corporate governance and firm value during the global financial crisis: evidence from China. International Review of Financial Analysis 21 (7), 70, 2012.

44. ZHANG F. Dual Embeddedness of governance and strategy - analysis based on interlocking directorate network. China Industrial Economics 9, 108, 2011.
45. ZHAO C., WANG Z.Q., YANG D., CAO W. Research on the catering behavior of enterprise and government subsidy performance: based on the analysis of the enterprise's profitability. China Industrial Economics 7, 130, 2015.

46. JENSEN M.C., MECKLING W.H. Theory of the firm: Managerial behavior,agency costs and ownership structure. Journal of Financial Economics 3 (4), 305, 1976.

47. LI D.Y., ZHENG M., CAO C.C., CHEN X.H., REN S.G., HUANG M. The impact of Legitimacy pressure and corporate profitability on green innovation: evidence from China top 100. Journal of Cleaner Production 141, 41, 2017.

48. BERRONE P., FOSFURI A., GELABERT L., GOMEZMEJIA L.R. Necessity as the mother of 'green' inventions: institutional pressures and environmental innovations. Strategic Management Journal 34 (8), 891, 2013.

49. WEN Z.L., YE B.J. Analyses of mediating effects: the development of methods and models. Advances in Psychological Science 22 (5), 731, 2014.

50. DU Y.Z., ZHANG Y.L., REN B. Show or hide the competitive advantage:The mediating role of competitors' orientation and performance U-type relationship and organizational legitimacy in new enterprises. Management World 7, 96, 2012.

51. EDWARDS J.R., LAMBERT L.S. Methods for integrating moderation and mediation: a general analytical frame work using moderated path analysis. Psychological Methods 12, $1,2007$.

52. WANG X.L., FAN G., HU L.P. Marketization Index of China's Provinces: Neri Report 2018. Beijing: Social Sciences Academic Press 2018.

53. CHEN C.C. An evaluation of optimal application of government subsidies on recycling of recyclable waste. Polish Journal of Environment Studies 14 (2), 137, 2005.

54. WANG X., WANG L. The major shareholders unavoidable: a new explanation for the failure of government subsidies on green innovation. R\&D Management, 32 (2), 2020.

55. JIN Z.J., XU J. Impact of Environmental Investment on Financial Performance: Evidence from Chinese listed Companies. Polish Journal of Environment Studies 29 (3), $2235,2020$. 